\title{
Pregnancy outcomes in asylum seekers in the North of the Netherlands: a retrospective documentary analysis
}

\author{
A. E. H. Verschuuren ${ }^{1 *}$ D, I. R. Postma ${ }^{1}$, Z. M. Riksen², R. L. Nott ${ }^{3}$, E. I. Feijen-de Jong ${ }^{4}$ and J. Stekelenburg ${ }^{1,5}$
}

\begin{abstract}
Background: With more than 20,000 asylum seekers arriving every year, healthcare for this population has become an important issue. Pregnant asylum seekers seem to be at risk of poor pregnancy outcomes. This study aimed to assess the difference in pregnancy outcomes between asylum seekers and the local Dutch population and to identify potential substandard factors of care.
\end{abstract}

Methods: Using a retrospective study design we compared pregnancy outcomes of asylum-seeking and Dutch women who gave birth in a northern region of the Netherlands between January 2012 and December 2016. The following data were compared: perinatal mortality, maternal mortality, gestational age at delivery, preterm delivery, birth weight, small for gestational age children, APGAR score, intrauterine foetal death, mode of delivery and the need for pain medication. Cases of perinatal mortality in asylum seekers were reviewed for potential substandard factors.

Results: A total of 344 Asylum-seeking women and 2323 Dutch women were included. Asylum seekers had a higher rate of perinatal mortality ( $3.2 \%$ vs. $0.6 \%, p=0.000)$ including a higher rate of intrauterine foetal death $(2.3 \% \mathrm{vs} .0 .2 \%$, $p=0.000)$, higher gestational age at birth ( $39+4$ vs. $38+6$ weeks, $p=0.000)$, labour was less often induced ( 36.9 vs. $43.8, p=0.016$ ), postnatal hospitalization was longer (2.24 vs. 1.72 days $p=0.006)$ and they received more opioid analgesics (27.3\% vs. 22\%, $p=0.029$ ). Babies born from asylum-seeking women had lower birth weights (3265 vs. 3385 $g, p=0.000)$ and were more often small for gestational age (13.9\% vs. $8.4 \%, p=0.002)$. Multivariate analysis showed that the increased risk of perinatal mortality in asylum-seeking women was independent of parity, birth weight and gestational age at birth. Review of the perinatal mortality cases in asylum seekers revealed possible substandard factors, such as late initiation of antenatal care, missed appointments because of transportation problems, not recognising alarm symptoms, not knowing who to contact and transfer to other locations during pregnancy.

Conclusion: Pregnant asylum seekers have an increased risk of adverse pregnancy outcomes. More research is needed to identify which specific risk factors are involved in poor perinatal outcomes in asylum seekers and to identify strategies to improve perinatal care for this group of vulnerable women.

Keywords: Asylum seekers, Pregnancy outcomes, Perinatal mortality, Vulnerable women, Substandard factors

\footnotetext{
* Correspondence: a.e.h.verschuuren@umcg.nl

1Department of Obstetrics and Gynaecology and Department of Health

Sciences, Global Health, University Medical Center Groningen/University of

Groningen, Hanzeplein, 19713 GZ Groningen, the Netherlands

Full list of author information is available at the end of the article
}

(c) The Author(s). 2020 Open Access This article is licensed under a Creative Commons Attribution 4.0 International License, which permits use, sharing, adaptation, distribution and reproduction in any medium or format, as long as you give appropriate credit to the original author(s) and the source, provide a link to the Creative Commons licence, and indicate if changes were made. The images or other third party material in this article are included in the article's Creative Commons licence, unless indicated otherwise in a credit line to the material. If material is not included in the article's Creative Commons licence and your intended use is not permitted by statutory regulation or exceeds the permitted use, you will need to obtain permission directly from the copyright holder. To view a copy of this licence, visit http://creativecommons.org/licenses/by/4.0/ The Creative Commons Public Domain Dedication waiver (http://creativecommons.org/publicdomain/zero/1.0/) applies to the data made available in this article, unless otherwise stated in a credit line to the data. 


\section{Background}

With more than 20,000 asylum seekers arriving in the Netherlands per year, health care for this vulnerable population has become an important point of interest [1-3]. Asylum seekers are refugees whose request for sanctuary has not been processed yet by the country they seek refuge in [4]. Of all asylum seekers, 25\% are women of reproductive age [5]. Research suggests that asylum-seeking women are disproportionately affected by health and social problems as compared to men, presumably because they are more vulnerable to physical assault and sexual harassment and they often feel their experiences and fears are not taken seriously [6].

A significant number of asylum-seeking women are or become pregnant during the time they seek refuge. Often, they arrive from countries with high rates of infectious disease, a poor health care system and have been persecuted, tortured or raped [7, 8]. During their flight circumstances are often primitive and dangerous. Once they arrive in the Netherlands, asylum seekers have little money, lack purpose in daily life and struggle with worries about the asylum procedure and the situation of family back home [7-9]. Research suggests that due to both the continuation of preexisting health problems $[10,11]$ and the result of economic hardship and social deprivation once seeking residence [12, 13], asylum seekers have poorer physical and mental health compared to local populations $[7,14,15]$. Access to health care services is difficult for asylum seekers because of a lack of culturally appropriate information and a limited understanding of the Dutch health care system $[9,16]$.

Literature suggests that pregnancy outcomes are worse in asylum seekers, with higher perinatal and maternal mortality as compared to autochthonous populations $[15,17-20]$. Studies in other countries show that refugee women have more complications such as low birth weight, low APGAR scores, preterm labour, anaemia, excessive bleeding during delivery and an increased incidence of Caesarean sections and admission of their child to the neonatal intensive care unit [11, 17, 20-24]. However, research on pregnancy outcomes on asylum seekers (i.e. those refugees whose request for sanctuary has not been processed yet) specifically is limited $[25,26]$. In the Netherlands asylum-seeking women show a 10-fold increase in maternal mortality, twice as much perinatal mortality and an increased risk of maternal morbidity, including a higher prevalence of uterine rupture, eclampsia, major obstetric haemorrhage and intensive care unit admission during pregnancy [27-30]. Additional perinatal outcomes in asylum seekers in the Netherlands have not been assessed. This study aims to assess the current difference in perinatal outcomes between asylum seekers and the local Dutch population in an area in the North of the Netherlands with a high density of asylum seekers. Also, cases of perinatal mortality in asylum seekers were reviewed. This information may help to identify specific areas of interest in pregnancy care for asylum-seeking women and act as guidance for health care providers to meet the maternity care needs of this vulnerable population.

\section{Methods \\ Study design}

We performed a cross-sectional database study using one midwifery practice and hospital databases to assess maternal and perinatal outcomes of asylum seekers and the local Dutch population in the North of the Netherlands.

\section{Setting}

In the Netherlands, asylum seekers live in asylum seekers centres during the processing of their request for sanctuary. In the North of the Netherlands, there are two major asylum seekers centres, Ter Apel and Musselkanaal. Ter Apel is the only central location of the Central Asylum Seeker Organization (COA; Centraal Orgaan Asielzoekers) in the Netherlands where asylum seekers who enter the country are accommodated at first instance. This resulted in a relatively high density of pregnant asylum-seeking women in the area.

\section{Maternity care in the Netherlands}

In the Netherlands, low-risk pregnancies are followed up by primary care midwives and family doctors (for nonpregnancy related complaints) [31]. Primary care consists of monthly visits, a check every two weeks in the last phase of the pregnancy, and then every week [32]. Secondary and tertiary care could only be accessed with referral and includes hospital specialist care.

\section{Data collection}

The data was retrieved from the primary and secondary care practices which provide the major part of pregnancy and delivery care to asylum-seeking women in Ter Apel and Musselkanaal. Databases were combined as described by Perined [33] to remove duplicate data of patients who were referred from primary to secondary care during pregnancy or delivery. Duplicate cases were identified by matching all cases on the mother's date of birth, due date, duration of pregnancy and the country of origin of the mother.

\section{Study population}

Asylum seekers who lived in Ter Apel or Musselkanaal and gave birth between January 2012 and December 2016 under the supervision of midwives from midwifery practice New Life or gynaecologists of the 
Refaja hospital were included in the study. Patients who were transferred to an asylum seeker centre elsewhere in the Netherlands before birth were excluded. The reference population consisted of the local Dutch population that gave birth under the supervision of the same care practices during the same time frame.

\section{Outcomes}

Demographic factors were reported, including age, the number of adolescent pregnancies (19years old or younger), country of origin, parity and uncertainty of due date. Parity was divided into 3 categories: nulliparous women, low multiparous women (1-3 previous deliveries) and grand multipara ( $>3$ previous deliveries). The outcome measures of this study were perinatal mortality (defined as death between 22 weeks of pregnancy and 7 days postpartum), maternal mortality, gestational age at delivery, preterm delivery (defined as delivery before 37 weeks of gestation), birth weight, small for gestational age children (SGA; defined as weight below the 10th percentile), APGAR score after $5 \mathrm{~min}$, intrauterine foetal death (IUFD), start of labour (spontaneous, induction or primary caesarean section), mode of delivery (spontaneous, vacuum/forceps assisted delivery or secondary caesarean section) and pain medication (opioid and epidural analgesia). Also, the Adverse Outcome Index-5 (AOI5) was calculated. The AOI-5 was designed to measure the magnitude of 5 adverse events that occurred during or around the delivery process [34]. It consists of perinatal mortality between a gestational age of 32 weeks and 7 days postpartum, neonatal intensive care unit (NICU) admission above 37 weeks, APGAR score lower than 7 after $5 \mathrm{~min}$, postpartum haemorrhage and third- or fourth-degree perineal laceration. The AOI is defined as the number of women with one or more adverse outcomes during birth as a proportion of all deliveries. All cases of perinatal mortality in asylum seekers were reviewed, aiming to find potential substandard factors. Information from the different patient files was analysed using a structured approach. The checklist included the age of the mother, gestational age at birth, a case description and the results additional examinations like autopsy and amniocentesis. After a review of the patient files, the potential substandard factors were identified.

\section{Statistical analysis}

All numerical values were tested for normality using Shapiro-Wilk's Test. Since there were no normally distributed values, values were presented using the median and range. Categorical values were compared using Chi-square or Fishers Exact test. The MannWhitney $U$ test was used to compare non-normally distributed and ordinal values. A logistic regression was performed to test for confounders for perinatal mortality. First, a univariate analysis was performed on possible confounding variables. All variables that showed a significant effect were included in a multivariate model. For the multivariate model a penalised likelihood logistic regression was used to reduce the chance of bias due to the low prevalence of perinatal mortality in our population. A value of $p<0.05$ was considered significant.

\section{Ethical considerations}

As this is an anonymous retrospective database study there were no specific ethical issues to be considered. By law, this study does not fall under the Medical Research Involving Human Subjects Act in the Netherlands.

\section{Results}

\section{Study population}

Data of 2028 Dutch and 285 asylum-seeking women were included from the hospital database and 868 Dutch and 485 asylum-seeking women from the midwifery practice database. 216 (45\%) pregnant women were transferred to an asylum-seeking centre elsewhere in the country before giving birth. After removing duplicates our study population included 2665 women: 344 asylum seekers and 2323 Dutch women.

Table 1 Demographic factors

\begin{tabular}{|c|c|c|c|}
\hline Characteristics & $\begin{array}{l}\text { Asylum } \\
\text { seekers } \\
(n=344)\end{array}$ & $\begin{array}{l}\text { Dutch } \\
\text { population } \\
(n=2323)\end{array}$ & $\begin{array}{l}p- \\
\text { value }\end{array}$ \\
\hline \multicolumn{4}{|l|}{ Age, years ${ }^{a}$} \\
\hline Median & 26 & 29 & 0.000 \\
\hline Range & $14-42$ & $15-45$ & \\
\hline Adolescent pregnancy & $30(8.7)$ & $48(2.1)$ & 0.000 \\
\hline \multicolumn{4}{|l|}{ Country of origin ${ }^{b}$} \\
\hline Netherlands & & $2323(100)$ & \\
\hline Syria & $75(21.8)$ & & \\
\hline Eritrea & 65 (18.9) & & \\
\hline Middle east & $75(21.8)$ & & \\
\hline Sub-Saharan Africa & $50(14.5)$ & & \\
\hline $\begin{array}{l}\text { Eastern Europe and the } \\
\text { former } \\
\text { Republic of Yugoslavia }\end{array}$ & $43(12.5)$ & & \\
\hline Other & $18(5.2)$ & & \\
\hline Parity & & & 0.000 \\
\hline Nulliparous & $170(49.4)$ & $1141(49.1)$ & \\
\hline Low multiparous $(1,2,3)$ & $153(44.5)$ & $1147(49.4)$ & \\
\hline Grand multipara $(\geq 4)$ & $21(6.1)$ & $35(1.5)$ & \\
\hline
\end{tabular}

Data are expressed as $\mathrm{n}(\%)$ except where otherwise indicated ${ }^{a}$ Missing data: 1 from the Dutch population

${ }^{\mathrm{b}}$ Missing data: 18 (5.2) from asylum seekers 


\section{Demographic variables}

Table 1 shows the demographic variables of both groups. Asylum seekers were younger $(p=0.000)$, had more adolescent pregnancies $(p=0.000)$ and there were more grand multipara women $(p=0.000)$ as compared to the control group. Most asylum seekers came from Syria $(n=75,21.8 \%)$ and Eritrea $(n=65$, $18.9 \%)$. Other countries were divided into categories based on geographical location.

\section{Pregnancy outcomes}

Asylum seekers showed a higher rate of perinatal mortality $(p=0.000)$ including a higher rate of intrauterine foetal death $(2.3 \%$ vs. $0.2 \%, \mathrm{p}=0.000)$, had a higher gestational age at delivery $(p=0.000)$, labour was less often induced $(p=0.016)$ and they more often received opioid analgesics $(p=0.029)$ as compared to Dutch women (Table 2). There was no significant difference in the frequency of epidural analgesia and APGAR scores after 5

Table 2 Pregnancy outcomes

\begin{tabular}{|c|c|c|c|}
\hline Indicator & $\begin{array}{l}\text { Asylum seekers } \\
(n=344)\end{array}$ & $\begin{array}{l}\text { Dutch population } \\
(n=2323)\end{array}$ & $p$ value \\
\hline Maternal mortality ${ }^{a}$ & $0(0)$ & $0(0)$ & - \\
\hline Perinatal mortality & $11(3.2)$ & $14(0.6)$ & 0.000 \\
\hline Gestational age at delivery in days ${ }^{b}$ & & & 0.000 \\
\hline Median & 277 & 272 & \\
\hline Range & $166-302$ & $112-296$ & \\
\hline Uncertain due date ${ }^{c}$ & $114(33.1)$ & $52(2.2)$ & 0.000 \\
\hline Prematurity (<37 weeks) & $44(12.8)$ & $248(10.7)$ & 0.242 \\
\hline Birth weight $^{d}$ & & & 0.000 \\
\hline Median & 3265 & 3385 & \\
\hline Range & $780-5050$ & $920-5100$ & \\
\hline$S G A^{e}$ & $41(13.9)$ & $172(8.4)$ & 0.002 \\
\hline APGAR score after 5 min & & & 0.054 \\
\hline Median (Mean) & $10(9.26)$ & $10(9.62)$ & \\
\hline Range & $0-10$ & $0-10$ & \\
\hline Postnatal hospitalization mother in days & & & 0.006 \\
\hline Median (Mean) & $1(2.24)$ & $1(1.72)$ & \\
\hline Range & $0-20$ & $0-27$ & \\
\hline IUFD & $8(2.3)$ & $4(0.2)$ & 0.000 \\
\hline \multicolumn{4}{|l|}{ Start of labour } \\
\hline Spontaneous start & $175(50.9)$ & $985(42.4)$ & 0.003 \\
\hline Inducing labour & $127(36.9)$ & $1018(43.8)$ & 0.016 \\
\hline Primary caesarean section & $42(12.2)$ & $320(13.8)$ & 0.429 \\
\hline \multicolumn{4}{|l|}{ Mode of delivery } \\
\hline Spontaneous birth & $188(54.7)$ & $1317(56.7)$ & 0.476 \\
\hline Vacuum or forceps assisted delivery & $63(18.3)$ & $371(16.0)$ & 0.272 \\
\hline Caesarean section & $93(27.0)$ & $635(27.3)$ & 0.907 \\
\hline \multicolumn{4}{|l|}{ Pain management } \\
\hline Opioid analgesic & $94(27.3)$ & $512(22.0)$ & 0.029 \\
\hline Epidural & 79 (23.0) & 438 (18.9) & 0.072 \\
\hline
\end{tabular}

Data are expressed as $\mathrm{n}(\%)$ except where otherwise indicated

SGA, Small for gestational age; IUFD, Intrauterine foetal death

${ }^{a}$ Missing data: 58 from Asylum seekers and 296 from Dutch population

${ }^{\mathrm{b}}$ Missing data: 1 from Dutch population

${ }^{\mathrm{C}}$ Missing data: 4 from Dutch population

dMissing data: 2 from asylum seekers and 10 from the Dutch population

eMissing data: 49 from Asylum seekers and 275 from Dutch population 
min. There were no cases of maternal mortality. Babies born from asylum-seeking women had lower birth weights $(p=0.000)$, were more likely to be small for gestational age $(p=0.002)$ and there were more uncertain due dates in the asylum-seeking population $(p=0.000)$ (Table 2). After removal of cases with an uncertain due date, there was still no difference in prematurity between the two groups $(p=0.459)$. The adverse outcome index showed no difference between groups $(p=0.529)$ (Table 3). There were no significant differences in pregnancy outcomes between the different countries of origin except for parity $(p=0.001)$, gestational age at delivery $(p=0.034)$, the number of women with an uncertain due date $(p=0.036)$ and the use of an epidural $(p=0.005)$. Notable was that there were more grand multipara pregnancies in the Middle Eastern (10.7\%) and the Eastern European (9.3\%) groups and that the use of epidural anaesthesia during delivery was lower in the Eritrean group (see Appendix Table 6). Parity, gestational age at birth and birth weight showed a significant relation to perinatal mortality in univariate regression (Table 4) and were therefore included in a multivariate model (Table 5). After correction for these variables, asylum seekers were 7.2 times more likely to experience perinatal mortality as compared to Dutch women.

\section{Review of perinatal mortality cases}

Of the eleven cases of perinatal mortality in asylum seekers, ten were intrauterine deaths and one child died within $24 \mathrm{~h}$ post-partum. The IUFD's were diagnosed at the gestational age of $23+4,23+6,24,25,30+2,34$, $34+4,34+6,36+3$ and $37+3$ weeks, respectively. All women had their first antenatal care appointment after a gestational age of thirteen weeks, with an average of $22+3$ weeks $(n=9,2$ unknown). Three women had no antenatal check-ups at all before an IUFD was discovered at respectively $33+2,34+5$ and $37+4$ weeks. Another three women had one or more documented missed antenatal care appointments. Two women missed appointments because they were transferred to a different centre. None of the eleven women took the recommended dosage of folic acid during pregnancy; nine women did not take folic acid at all. Two women had a recorded history of mental health problems and in two cases there was substance abuse during pregnancy. In one of the cases, there was a multiple pregnancy with twin to twin transfusion syndrome. Intrauterine growth restriction was recorded in three cases and one woman developed preeclampsia. Further review of these cases revealed that in six cases there was a delay in seeking care when a woman experienced alarming symptoms: four women felt reduced foetal movement, for two and three days respectively, three weeks and a month before visiting a midwife. One of them did not know who to call during the weekend. One case of neonatal mortality within $24 \mathrm{~h}$ post-partum involved a woman who was losing green fluid with reduced foetal movement for three days, and an emergency caesarean section was performed because of signs of foetal distress. The child was born with APGAR scores of one after one, five and ten minutes and was anaemic. In six cases obduction was performed, which revealed two lightweight placentas showing maternal vascular malperfusion and one child had a trisomy 21 .

\section{Discussion}

This study aimed to assess the difference in maternal and perinatal outcomes between asylum seekers and the local Dutch population in the North of the Netherlands and identify potential substandard factors in the care for asylum seekers. In this study perinatal mortality was higher in asylum seekers, birth weight

Table 3 Adverse Outcome Index-5

\begin{tabular}{|c|c|c|c|}
\hline Indicator & $\begin{array}{l}\text { Asylum seekers } \\
(n=344)\end{array}$ & $\begin{array}{l}\text { Dutch population } \\
(n=2323)\end{array}$ & $p$ value \\
\hline Perinatal mortality ( $>32$ weeks and $<7$ days postpartum) ${ }^{a}$ & $2(0.7)$ & $2(0.1)$ & 0.078 \\
\hline APGAR score $<7$ after 5 min $^{b}$ & $12(4.1)$ & $41(2.0)$ & 0.023 \\
\hline NICU admission (> 37 weeks) ${ }^{c}$ & $5(1.7)$ & $16(0.8)$ & 0.171 \\
\hline Perineum Laceration (3rd or 4th degree) ${ }^{d}$ & $4(1.4)$ & $46(2.3)$ & 0.346 \\
\hline Postpartum haemorrhage ${ }^{e}$ & $15(5.2)$ & $162(7.9)$ & 0.103 \\
\hline AOl-5 score ${ }^{f}$ & $33(11.1)$ & $257(12.4)$ & 0.529 \\
\hline
\end{tabular}

NICU Neonatal intensive care unit, $A O I$ Adverse outcome index

${ }^{a}$ Missing data: 57 from Asylum seekers and 295 from the Dutch population

${ }^{b}$ Missing data: 54 from Asylum seekers and 288 from the Dutch population

${ }^{\mathrm{C}}$ Missing data: 54 from Asylum seekers and 289 from the Dutch population

${ }^{\mathrm{d}}$ Missing data: 55 from Asylum seekers and 293 from the Dutch population

e Missing data: 55 from Asylum seekers and 272 from the Dutch population

${ }^{f}$ Missing data: 48 from Asylum seekers and 256 from the Dutch population 
Table 4 Univariate logistic regression predicting the likelihood of perinatal mortality

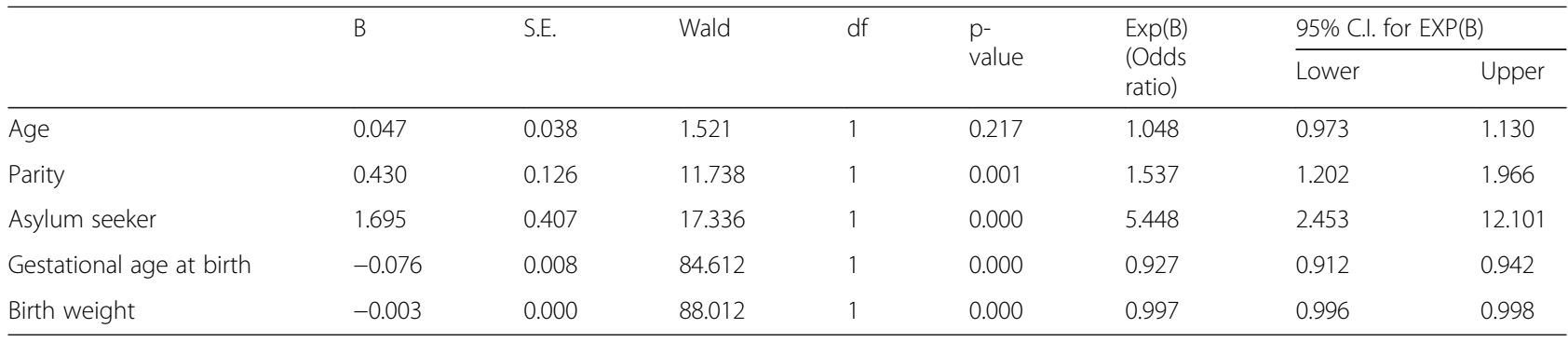

and APGAR scores were lower and postnatal hospitalization was longer compared to Dutch women. Labour in asylum seekers was less often induced, opioid analgesics were administered more often and there were more adolescent pregnancies. There was no difference in preterm birth rate and the mode of delivery, nor in the adverse outcome index. No cases of maternal mortality were recorded in this study. Overall the findings of our study were in line with previous research $[15,18-21,23,25,30-32]$. We found that, even after correcting for confounders, perinatal mortality was higher in asylum seekers. Review of these cases revealed possible substandard factors causing a delay in the first two phases of the Three Delays Model (deciding to seek care and reaching the healthcare facility [35]), consisting of late initiation of antenatal care, missed appointments because of problems with transportation, not recognizing alarm symptoms, not knowing who to contact and transfer during pregnancy. Our findings reenforce those from previous studies and also identify additional delays in the third step of the model (receiving adequate care), such as a language barrier, fear of mistreatment, shame and non-availability of a female doctor $[11,13,15,23,36-38]$. All these factors may contribute to the limited use of antenatal care in asylum-seeking women [13, 18, 20, 39-41]. Poor attendance to antenatal care has been associated with poor pregnancy outcomes [42, 43]. Previous studies showed that a lack of antenatal care results in lower folic acid intake [44], which has been described to increase the risk of low birth weight [45]. This may have played a role in our population as we indeed found lower birth weight and a higher prevalence of SGA children in asylum seekers. Our study was not powered to detect a difference in maternal mortality since the incidence of maternal mortality in the Netherlands is 7 deaths per 100,000 live births [46]. Previous studies suggest that maternal mortality is higher among asylum seekers [13, 15, 27, 28].

We found that the use of opioid analgesics was higher in asylum-seeking women as compared to the Dutch group. A potential reason for this may be because coaching these women can be a bigger challenge for a caregiver due to a language barrier and cultural differences. However, there was no difference in the use of epidural anaesthesia. In our study, the rate of labour induction was higher in Dutch women. Previous research showed conflicting results about the difference in labour induction between groups [39, 47]. The option of labour induction after 41 weeks of gestation is discussed with patients in the Netherlands. It is possible that asylumseeking women might not know of the possibility, due to less antenatal care visits and a language barrier. In our study, postnatal hospital stay was significantly longer in asylum-seeking mothers as opposed to other studies [20, 48]. A lack of facilities and social support at home could contribute to this.

Table 5 Multivariate penalised likelihood logistic regression predicting the likelihood of perinatal mortality

\begin{tabular}{|c|c|c|c|c|c|c|c|c|}
\hline & \multirow[t]{2}{*}{ B } & \multirow[t]{2}{*}{ S.E. } & \multirow[t]{2}{*}{ Wald } & \multirow[t]{2}{*}{$d f$} & \multirow{2}{*}{$\begin{array}{l}p^{-} \\
\text {value }\end{array}$} & \multirow{2}{*}{$\begin{array}{l}\operatorname{Exp}(B) \\
\text { (Odds } \\
\text { ratio) }\end{array}$} & \multicolumn{2}{|c|}{ 95\% C.I. for EXP(B) } \\
\hline & & & & & & & Lower & Upper \\
\hline Constant & 5.572 & 2.915 & 4.028 & 1 & 0.045 & 262.946 & 0.123 & 11.913 \\
\hline Asylum seeker & 1.976 & 0.609 & 10.213 & 1 & 0.001 & 7.212 & 0.776 & 3.248 \\
\hline Birth weight & -0.002 & 0.001 & 7.599 & 1 & 0.006 & 0.998 & -0.004 & -0.001 \\
\hline Gestational age at birth & -0.022 & 0.018 & 1.558 & 1 & 0.212 & 0.978 & -0.061 & 0.012 \\
\hline
\end{tabular}

Likelihood ratio test $=181.108$ on $3 \mathrm{df}, \mathrm{p}=0, \mathrm{n}=2654$

Wald test $=88.535$ on $3 \mathrm{df}, \mathrm{p}=0$ 
This study did not observe differences in the incidence of preterm birth, low APGAR scores, adverse outcome index, NICU admission, perineum laceration, postpartum haemorrhage, mode of delivery and the rate of epidural analgesia. Previous studies showed similar results, except for a higher rate of epidural analgesia use during labour in local populations and lower APGAR scores in asylum seekers $[17,20,23$, $39,47,49]$.

Finally, ours and other studies showed that asylumseeking women were on average younger and had a higher parity rate $[17,20,23,39,47,48]$. The higher parity rate in asylum seekers could be attributed to cultural differences and little control over family planning decisions, including access to contraceptives [18]. Other studies showed that grand multipara women had a higher incidence of maternal morbidity and therefore poorer perinatal outcomes [50] however in our study, parity and age showed no relation to perinatal mortality in multivariate analysis. An uncertain estimated date of delivery was more common in asylum seekers because of a lack of ultrasounds in early pregnancy. Therefore, the rate of premature children and SGA in this study could be underestimated. We found no significant differences in pregnancy outcomes between the different countries of origin in the asylum-seeking group.

\section{Strengths and limitations}

This was the first study comparing a wide range of pregnancy outcomes in asylum seekers and Dutch women. This study included asylum seekers from different countries of origin, while previous studies often included asylum seekers from one specific background. Our sample size $(n=2665)$ was large compared to previous studies whose sample sizes were all smaller than 1500 women with only two previous studies exceeding 1000 participants.

A language barrier plays a role with most pregnant asylum seekers, however, because of the retrospective character of the study there was not sufficient information to which extent this language barrier played a role and if and how often official translator services were used. Maternal mortality was also not assessed in this study. Our group was too small to assess the difference in maternal mortality and maternal morbidity between groups. For this study, we only included data from one hospital and one midwife practice. However, these facilities have vast experience in caring for asylum seeking women since the asylum-seeking centre in Ter Apel is the largest centre in the Netherlands. Also, the control group consisted of women from the northern Netherlands which was a region where a relatively large proportion of the population had a low socioeconomic status. Therefore, the control group might not have been representative of the general Dutch population. Differences in outcomes between the general Dutch population and asylum seekers may be even larger.

\section{Implications for care providers}

This study highlights the importance of improving care for pregnant asylum seekers. Extra attention should be paid to asylum-seeking women during pregnancy by health care providers with the ultimate goal to achieve equity in health. Our study identifies possible substandard factors of the current care system which could facilitate the development of effective health care interventions. Alternative forms of antenatal care for asylumseeking women targeting the identified substandard factors should be developed. In the North of the Netherlands, we are currently working with a group antenatal care program specifically for asylum-seeking women.

In this study $45 \%$ of the asylum seekers were transferred to another centre during pregnancy causing discontinuation of antenatal care. Transfer between asylum-seeking centres during pregnancy should be minimized to reduce suboptimal care for an already vulnerable population.

\section{Further research}

To provide more data about perinatal outcomes in asylum seekers, larger prospective multicentre studies should be conducted. Comparing the difference in perinatal outcome between different countries of origin might give insight in which women within the asylum-seeking population are extra vulnerable. Since antenatal care use is limited in asylum seekers, alternative forms of antenatal care and its effect on pregnancy outcomes should be studied. We are currently studying whether group antenatal care as compared to standard antenatal care in the Netherlands improves pregnancy outcomes and satisfaction with care in asylum seekers. Also, psychosocial factors and the incidence of mental health problems in asylum seekers should be studied.

\section{Conclusion}

Perinatal outcomes in asylum seekers appear to be worse compared to Dutch women. Extra attention should be paid to pregnant asylum seekers to make sure quality maternity care is provided. This study highlights that reducing disparities in pregnancy outcomes between asylum seekers and Dutch women should be an important public health goal in the Netherlands. Further large-scale research should be conducted to improve antenatal care for pregnant asylum seekers and to identify specific risk factors for poor perinatal outcomes in asylum seekers. 


\section{Appendix}

Table $\mathbf{6}$ differences in pregnancy outcomes between different origins

\begin{tabular}{|c|c|c|c|c|c|c|c|}
\hline Characteristics & $\begin{array}{l}\text { Eritrea } \\
(\boldsymbol{n}=65)\end{array}$ & $\begin{array}{l}\text { Syria } \\
(\boldsymbol{n}=75)\end{array}$ & $\begin{array}{l}\text { Middle east } \\
(\boldsymbol{n}=75)\end{array}$ & $\begin{array}{l}\text { Sub-Saharan Africa } \\
(\boldsymbol{n}=50)\end{array}$ & $\begin{array}{l}\text { Eastern Europe } \\
(\boldsymbol{n}=43)\end{array}$ & $\begin{array}{l}\text { Other } \\
(\boldsymbol{n}=18)\end{array}$ & $\boldsymbol{p}$-value \\
\hline Age, years & & & & & & & 0.592 \\
\hline Median & 25 & 26 & 25 & 29 & 28 & 26 & \\
\hline Range & $17-42$ & $14-41$ & $17-41$ & $19-41$ & $18-38$ & $18-40$ & \\
\hline Adolescent pregnancy & $6(9.2)$ & $7(9.3)$ & $6(8.0)$ & $2(4.0)$ & $4(9.3)$ & $2(11.1)$ & 0.895 \\
\hline Parity & & & & & & & 0.001 \\
\hline Nulliparous & $44(67.7)$ & $31(41.3)$ & $42(56.0)$ & $26(52.0)$ & $11(25.6)$ & $8(44.4)$ & \\
\hline Low multiparous $(1,2,3)$ & $20(30.8)$ & $41(54.7)$ & $25(33.3)$ & $22(44.0)$ & $28(65.1)$ & $9(50.0)$ & \\
\hline Grand multipara $(\geq 4)$ & $1(1.5)$ & $3(4.0)$ & $8(10.7)$ & $2(4.0)$ & $4(9.3)$ & $1(5.6)$ & \\
\hline Maternal mortality & $0(0)$ & $0(0)$ & $0(0)$ & $0(0)$ & $0(0)$ & $0(0)$ & - \\
\hline Perinatal mortality & $1(1.5)$ & $4(5.3)$ & $3(4.0)$ & $2(4.0)$ & $0(0)$ & $0(0)$ & 0.535 \\
\hline Gestational age at delivery in days & & & & & & & 0.034 \\
\hline Median & 280 & 275 & 275 & 279 & 279 & 270 & \\
\hline Range & $203-302$ & $175-295$ & $167-294$ & $166-302$ & $229-294$ & $251-294$ & \\
\hline Uncertain due date & $29(44.6)$ & $20(26.7)$ & $25(33.3)$ & $17(34.0)$ & $7(16.3)$ & $8(44.4)$ & 0.036 \\
\hline Prematurity (< 37 weeks) & $6(9.2)$ & $9(12.0)$ & $5(6.7)$ & $7(14.0)$ & $6(14.0)$ & $4(22.2)$ & 0.452 \\
\hline Birth weight ${ }^{a}$ & & & & & & & 0.122 \\
\hline Median & 3343 & 3200 & 3300 & 3140 & 3320 & 3123 & \\
\hline Range & $1665-4320$ & $780-4245$ & $1780-4395$ & $1415-4360$ & $1662-5050$ & $2305-4685$ & \\
\hline $\mathrm{SGA}^{\mathrm{b}}$ & $8(12.3)$ & $9(12.0)$ & $6(8.0)$ & $7(14.0)$ & $6(14.0)$ & $3(16.7)$ & 0.892 \\
\hline APGAR score after $5 \mathrm{~min}$ & & & & & & & 0.491 \\
\hline Median (Mean) & $10(9.31)$ & $10(9.24)$ & $10(9.29)$ & $10(9.00)$ & $10(9.58)$ & $10(9.61)$ & \\
\hline Range & $0-10$ & $0-10$ & $0-10$ & $0-10$ & $6-10$ & $4-10$ & \\
\hline Postnatal hospitalization mother in days ${ }^{c}$ & & & & & & & 0.168 \\
\hline Median (Mean) & $1.5(2.17)$ & $1(2.51)$ & $1(1.88)$ & $2(2.21)$ & $1(2.00)$ & $2(3.06)$ & \\
\hline Range & $0-10$ & $0-20$ & $0-10$ & $0-10$ & $0-12$ & $1-8$ & \\
\hline IUFD & $1(1.5)$ & $3(4.0)$ & $2(2.7)$ & $1(2.0)$ & $0(0)$ & $0(0)$ & 0.734 \\
\hline Start of labour & & & & & & & 0.534 \\
\hline Spontaneous start & $30(46.2)$ & $32(42.7)$ & $45(60.0)$ & $25(50.0)$ & $23(53.5)$ & $8(44.4)$ & \\
\hline Inducing labour & $29(44.6)$ & $31(41.3)$ & $24(32.0)$ & $18(36.0)$ & $16(37.2)$ & $6(33.3)$ & \\
\hline Primary caesarean section & $6(9.2)$ & $12(16.0)$ & $6(8.0)$ & $7(14.0)$ & $4(9.3)$ & $4(22.2)$ & \\
\hline Mode of delivery & & & & & & & 0.529 \\
\hline Spontaneous birth & $30(46.2)$ & $41(54.7)$ & $47(62.7)$ & $25(50.0)$ & $29(67.4)$ & $9(50.0)$ & \\
\hline Vacuum or forceps assisted delivery & $16(24.6)$ & $12(16.0)$ & $13(17.3)$ & $9(18.0)$ & $5(11.6)$ & $4(22.2)$ & \\
\hline Caesarean section & $19(29.2)$ & $22(29.3)$ & $15(20.0)$ & $16(32.0)$ & $9(20.9)$ & $5(27.8)$ & \\
\hline \multicolumn{8}{|l|}{ Pain management } \\
\hline Opioid analgesic & $22(33.8)$ & $14(18.7)$ & $23(30.7)$ & $15(30.0)$ & $8(18.6)$ & $7(38.9)$ & 0.174 \\
\hline Epidural & $6(9.2)$ & $26(34.7)$ & $23(30.7)$ & $10(20.0)$ & $9(20.9)$ & $2(11.1)$ & 0.005 \\
\hline
\end{tabular}

Data are expressed as $\mathrm{n}(\%)$ except where otherwise indicated

SGA Small for gestational age, IUFD, Intrauterine foetal death

Missing data: 18 asylum seeking women had no recorded country of origin so were not included in this table

${ }^{a}$ Missing data: 1 Middle Eastern and 1 Sub Saharan Africa

${ }^{\mathrm{b} M i s s i n g}$ data: 10 Eritrea, 11 Syria, 9 Middle Eastern, 5 Sub Saharan Africa, 5 Eastern Europe and 2 other

'Missing data: 1 Eritrea, 1 Syria, 6 Middle Eastern, 3 Sub Saharan Africa, 3 Eastern Europe and 2 other 


\section{Alternative forms of antenatal care and its effect on pregnancy outcomes in asylum seekers need to be studied.}

\section{Abbreviations}

AOI: Adverse outcome index; IUFD: Intrauterine foetal death; NICU: Neonatal intensive care unit; SGA: Small for gestational age

\section{Acknowledgements}

Not applicable.

\section{Authors' contributions}

AEHV combined the databases, analysed and interpreted the data, reviewed the perinatal mortality cases and wrote the manuscript. IRP was the direct supervisor and guided AEHV through all steps of the process. JS and EIFJ were involved in the setup of the study and writing the manuscript. RLN and ZMR provided the data for the database and gave AEHV access to the patient files for the review of the perinatal mortality cases. All authors read and approved the final manuscript.

\section{Authors' information}

Not applicable

\section{Funding}

There is no funding for this research to declare.

\section{Availability of data and materials}

The datasets used and analysed during the current study are available from the corresponding author on reasonable request.

\section{Ethics approval and consent to participate}

As this is an anonymous retrospective database study there were no specific ethical issues to be considered. By law, this study does not fall under the Medical Research Involving Human Subjects Act in the Netherlands. The study proposal was submitted to the Medical Ethical Committee of the University Medical Center Groningen. The committee has reviewed the proposal and has waived the need for ethics approval.

\section{Consent for publication}

All authors read and approved the final manuscript for publication.

\section{Competing interests}

The authors declare that they have no competing interests.

\section{Author details}

'Department of Obstetrics and Gynaecology and Department of Health Sciences, Global Health, University Medical Center Groningen/University of Groningen, Hanzeplein, 19713 GZ Groningen, the Netherlands. 'Refaja ziekenhuis Stadskanaal, Boerhaavestraat, 19501 HE, Stadskanaal, the Netherlands. ${ }^{3}$ New Life, Sperwerlaan, 179561 BG Ter Apel, the Netherlands. ${ }^{4}$ Department of General Practice \& Elderly Medicine, University Medical Center Groningen, University of Groningen, Dirk Huizingastraat 3, 59713 GL Groningen, the Netherlands. ${ }^{5}$ Department Obstetrics and Gynaecology, Medical center Leeuwarden, Henri Dunantweg 2, AD 8934 Leeuwarden, the Netherlands.

\section{Received: 24 April 2019 Accepted: 4 May 2020}

Published online: 25 May 2020

\section{References}

1. Asielverzoeken en nareizigers; nationaliteit, geslacht en leeftijd [Internet]. CBS. 2018 [cited 2019 May 7]. Available from: https://opendata.cbs.nl/ statline/\#/CBS/nl/dataset/83102NED/table?ts=1529128026717.

2. Dutch ministry of safety and justice. Rapportage Vreemdelingenketen periode januari-december 2016 (Immigration report 2016). https://www. rijksoverheid.nl/documenten/rapporten/2017/03/21/rapportagevreemdelingenketen-periode-januari-december-2016.

3. Dutch ministry of safety and justice. Rapportage Vreemdelingenketen periode januari-december 2017 (Immigration report 2017). https://www. rijksoverheid.nl/documenten/rapporten/2018/04/30/rapportagevreemdelingenketen-periode-januari-december-2017.

4. United Nations High Commissioner for refugees (UNHCR). Asylum-Seekers [Internet]. [cited 2018 Jan 5]. Available from: http://www.unhcr.org/pages/4 9c3646c137.html.

5. Sexual and reproductive health and rights of refugees and migrants [Internet]. World Health Organization; 2016 [cited 2019 May 5]. Available from: http:// www.who.int/reproductivehealth/news/srhr-refugees-migrant/en/.

6. Feldman R, Action M, Council R. When maternity doesn't matter: dispersing pregnant women seeking asylum. Reprod Health Matters. 2013;21(42):212-7.

7. Vink M, Wijk van R. Asielzoeker is geen gewone patiënt 2009. Med Contact (Bussum). 2009;64(5):209-11.

8. Balaam MC, Kingdon C, Thomson G, Finlayson K, Downe S. "We make them feel special": the experiences of voluntary sector workers supporting asylum seeking and refugee women during pregnancy and early motherhood. Midwifery. 2016;34:133-40.

9. Mazhar M. The Impact of Jordanian Health Care Policy on the Maternal and Reproductive Health Care Seeking Behavior of Syrian Refugee Women 2015. Independent Study Project (ISP) Collection. Paper 2057. http:// digitalcollections.sit.edu/isp_collection/2057.

10. Burnett A, Peel M, Bmj S, Medical B, Mar N, Burnett A, et al. Asylum seekers and refugees in Britain: health needs of asylum seekers and refugees linked. Br Med J. 2001;322(7285):544-7.

11. Carolan M, Lecturer S. Pregnancy health status of sub-Saharan refugee women who have resettled in developed countries : a review of the literature. Midwifery. 2010;26(4):407-14.

12. Burchill J. Safeguarding vulnerable families: work with refugees and asylum seekers. Community Pract. 2011;84(2):23-6.

13. Keygnaert I, Ivanova O, Guieu A, et al. Health Evidence Network Synthesis Report, No. 45. 2016

14. Gerritsen AA, Deville W, der FA L v, Bramsen I, Willigen van LHM. Psychische en lichamelijke gezondheidsproblemen van en gebruik van zorg door Afghaanse, Iraanse en Somalische asielzoekers en vluchtelingen. Ned Tijdschr Geneeskd. 2006;150(36):1983-9.

15. Mander R, Smith GD. Saving Mothers' Lives (formerly Why Mothers die): reviewing maternal deaths to make motherhood safer 2003-2005. Midwifery. 2008;24(1):8-12. https://doi.org/10.1016/j.midw.2008.01.008.

16. Davidson N, Skull S, Burgner D, Kelly P, Raman S, Silove D, et al. An issue of access: delivering equitable health care for newly arrived refugee children in Australia. J Paediatr Child Health. 2004;40:569-75.

17. Alnuaimi K, Kassab M, Ali R, Mohammad K, Shattnawi K. Pregnancy outcomes among Syrian refugee and Jordanian women: a comparative study. Int Nurs Rev. 2017;64(4):584-92.

18. Benage $M$, Greenough $P$, Vinck P, Omeira N, Pham P. An assessment of antenatal care among Syrian refugees in Lebanon. Confl Health. 2015;9(1):8.

19. About the Maternity Stream of the City of Sanctuary [Internet]. [cited 2017 Oct 17]. Available from: https://maternity.cityofsanctuary.org/about.

20. Michaan N, Gil Y, Amzalag S, Laskov I, Lessing J, Many A. Perinatal outcome, social and financial impact of african refugees delivered in a tertiary hospital in Tel-Aviv, Israel. Reprod Sci. 2014;16:371-174.

21. Hamad KH, Abed Y, Hamed B. Risk factors associated with preterm birth in the Gaza strip: hospital based case-control study. East Meditaranean Heal J. 2007;13(5):1132-41.

22. Masterson A, Usta J, Gupta J, Ettinger A. Assessment of reproductive health and violence against women. BMC Womens Health. 2014;14(25):1-8.

23. Kandasamy T, Cherniak R, Shah R, Yudin MH, Spitzer R. Obstetric risks and outcomes of refugee women at a single Centre in Toronto. J Obstet Gynaecol Canada. 2014;36(4):296-302.

24. Bollini P, Pampallona S, Wanner P, Kupelnick B. Pregnancy outcome of migrant women and integration policy : a systematic review of the international literature. Soc Sci Med. 2009;68(3):452-61.

25. Heslehurst N, Brown H, Pemu A, Coleman H, Rankin J. Perinatal health outcomes and care among asylum seekers and refugees: a systematic review of systematic reviews. BMC Med. 2018;16(1):1-25.

26. Gieles NC, Tankink JB, van Midde M, Duker J, Van Der Lans P, Wessels CM, et al. Systematic review and Meta analyses maternal and perinatal outcomes of asylum seekers and undocumented migrants in Europe : a systematic review. Eur J Pub Health. 2019;29(4):714-23.

27. van Oostrum IEA, Goosen S, Uitenbroek DG, Koppenaal H, Stronks K. Mortality and causes of death among asylum seekers in the Netherlands, 2002-2005. J Epidemiol Community Heal. 2011;65(4):376-83. 
28. Goosen S, Van Oostrum IEA, Essink-bot M. Zwangerschapsuitkomsten en zorgbehoeften bij asielzoeksters. Ned Tijdschr Geneeskd. 2010;154:1-7.

29. Zwart JJ, Jonkers MD, Richters A, Öry F, Bloemenkamp KW, Duvekot JJ, et al. Ethnic disparity in severe acute maternal morbidity: a nationwide cohort study in the Netherlands. Eur J Pub Health. 2011;21(2):229-34.

30. Schuitemaker N, Van Roosmalen J, Dekker G, Van Dongen P, Van Geijn H, Gravenhorst JB. Confidential enquiry into maternal deaths in the Netherlands 1983-1992. Eur J Obstet Gynecol. 1998;79(1):57-62.

31. Koninklijke Nederlandse Organisatie van Verloskundigen. De Nederlandse geboortezorg [Internet]. 2018 [cited 2018 Sep 10]. Available from: https:// www.knov.nl/over-de-knov/tekstpagina/781-3/de-nederlandsegeboortezorg/hoofdstuk/1095/de-nederlandse-geboortezorg/.

32. de Boer J, Zeeman K. KNOV-standaard Prenatale verloskundige begeleiding (Dutch prenatal midwife care guide). Koninklijke Nederlandse Organisatievan Verloskundige (Dutch royal organisation for Obstetrics). 2008. http://www.knov.nl/uploads/knov.nl/knov_downloads/791/file/ KNOVStandaard\%20Prenatale\%20verloskundige\%20begeleiding.pdf.

33. Perined. Perined-Koppelingsprocedure 2014: LVR1-, LVRh-, LVR2- en LNRdeelregistraties. 2015. https://perined-assets.e-dev.nl/docs/b5252b5a-eeae-4 ba0-82f8-cbfoc99597be.pdf.

34. Foglia LM, Nielsen PE, Hemann EA, Walker S, Pates JA, Napolitano PG, et al. Accuracy of the adverse outcome index: an obstetrical quality measure. Jt Comm J Qual Patient Saf. 2015:41(8):370-7.

35. Thaddeus S, Maine D. Too far to walk: maternal mortality in context. Soc Sci Med. 1994;38(8):1091-110.

36. McKeary M, Newbold B. Barriers to care: the challenges for Canadian refugees and their health care providers. J Refug Stud. 2010;23(4):523-45.

37. Yelland J, Riggs E, Small R, Brown S. Maternity services are not meeting the needs of immigrant women of non-English speaking background : results of two consecutive Australian population based studies. Midwifery. 2015; 31(7):664-70.

38. Puthussery S, Lecturer S. Best Practice \& Research Clinical Obstetrics and Gynaecology Perinatal outcomes among migrant mothers in the United Kingdom : Is it a matter of biology , behaviour, policy, social determinants or access to health care ? Best Pract Res Clin Obstet Gynaecol. 2016;32:39-49.

39. Erenel H, Aydogan Mathyk B, Sal V, Ayhan I, Karatas S, Koc BA. Clinical characteristics and pregnancy outcomes of Syrian refugees: a case-control study in a tertiary care hospital in Istanbul, Turkey. Arch Gynecol Obstet. 2017;295(1):45-50

40. Correa-Velez I, Ryan J. Developing a best practice model of refugee maternity care. Women Birth. 2012;25:13-22.

41. Ministerie van Volksgezondheid W en S (Dutch ministry of Health, Welfare and Sport). Inzet professionele tolken en overdracht bij overplaatsing moetenbeter voor verantwoorde geboortezorg aan asielzoekers [Internet]. 2014. Available from: https://www.igz.n//Images/2014-02. Geboortezorgaanasiekzoekerstcm294-351517.pdf.

42. Hollowell J, Oakley L, Vigurs C, Barnett-page E, Kavanagh J, Oliver S. Increasing the early initiation of antenatal care by Black and Minority Ethnicwomen in the United Kingdom: a systematic review and mixed methods synthesis of women's views and the literature on intervention effectiveness. Oxford: National Perinatal Epidemiology Unit University of Oxford; 2012.

43. Abdal Q, Badilla MA, Mohd I, Amin R, et al. Influence of antenatal care on birth weight: a cross sectional study in Baghdad City, Iraq. BMC PublicHealth. 2012;12:A38.

44. Lunet N, Rodrigues T, Correia S, Barros H. Adequacy of prenatal care as amajor determinant of folic acid, iron, and vitamin intake during pregnancy. Cad Saude Publica. 2008;24(5):1151-7.

45. Lassi ZS, Salam RA, Haider BA, Bhutta ZA. Folic acid supplementation during pregnancy for maternal health and pregnancy outcomes. Cochrane Database Syst Rev. 2013;(3).

46. Central intelligence agency. The world factbook: Maternal mortality ratio [Internet]. [cited 2018 Feb 1]. Available from: https://www.cia.gov/library/ publications/the-world-factbookffields/2223.html\#nl.

47. Yoong W, Wagley A, Fong C, Chukwuma C, Nauta M. Obstetric performance of ethnic Kosovo Albanian asylum seekers in London: a case-control study. J Obstet Gynaecol (Lahore). 2004;24(5):510-2.

48. Demirci H, Yildirim Topak N, Ocakoglu G, Karakulak Gomleksiz M, Ustunyurt E, Ulku TA. Birth characteristics of Syrian refugees and Turkish citizens in Turkey in 2015. Int J Gynecol Obstet. 2017;137(1):63-6.
49. Yoong W, Kolhe S, Karoshi M, Ullah M, Nauta M. The obstetric performance of United Kingdom asylum seekers from Somalia: a case-control study and literature review. Int J Fertil Womens Med. 2005;50(4):175-9.

50. Bai J, Wong FWS, Bauman A, Mohsin M. Parity and pregnancy outcomes. Am J Obstet Gynecol. 2002;186(2):274-8.

\section{Publisher's Note}

Springer Nature remains neutral with regard to jurisdictional claims in published maps and institutional affiliations.
Ready to submit your research? Choose BMC and benefit from:

- fast, convenient online submission

- thorough peer review by experienced researchers in your field

- rapid publication on acceptance

- support for research data, including large and complex data types

- gold Open Access which fosters wider collaboration and increased citations

- maximum visibility for your research: over $100 \mathrm{M}$ website views per year

At BMC, research is always in progress.

Learn more biomedcentral.com/submissions 